\title{
PERANCANGAN SISTEM TATA UDARA PADA RUANG NICU DI LANTAI 3 RUMAH SAKIT " $X$ "
}

\author{
Annisa Pramudhita ${ }^{1}$, Rudi Hermawan ${ }^{2}$ \\ 1,2 Departemen Teknik Mesin, Fakultas Teknik, Universitas Pancasila, DKI Jakarta 12640 Indonesia \\ Email: ${ }^{1}$ annisapramudhita@gmail.com, ${ }^{2}$ defaangkasa@yahoo.com
}

\begin{abstract}
Abstrak
Salah satu upaya untuk mengurangi Hospital-acquired Infections (HAIs, atau yang biasa disebut dengan infeksi nosokomial) pada ruang NICU, adalah dengan merancang sistem tata udara khusus, yang ASHRAE HVAC Design Manual for Hospital and Clinics. Parameterparameter yang perlu dikondisikan dalam sistem tata udara yaitu suhu, kelembaban udara relatif, tekanan ruangan, kebersihan udara, ventilasi, distribusi udara pada ruangan. Metode perhitungan kapasitas pendinginan yang digunakan dalam penelitian ini adalah dengan menggunakan Cooling Load Temperature Difference (CLTD). Sedangkan metode yang digunakan dalam merancang saluran distribusi udara adalah metode Equal Friction Loss. Dari hasil perhitungan, didapat kapasitas pendinginan yang dihasilkan oleh ruang NICU adalah sebesar 8,803 kW. Sedangkan kapasitas pemanasannya adalah sebesar 3,660 kW. Nilai total pressure loss untuk saluran udara yang dirancang adalah sebesar 44,85 Pa. Filter yang built-in dengan unit $\mathrm{AC}$ adalah pre-filter dan medium filter. Sehingga, HEPA filter diletakkan pada ceiling.
\end{abstract}

Kata Kunci: Sistem Tata Udara, Ruang NICU, HAIs, CLTD

\begin{abstract}
In order to reduce nosocomial infections, or generally known as Hospital-acquired Infections (HAIs) in NICU room, a special design of air conditioning system is needed, as per HVAC Design Manual for Hospital and Clinics. There are several parameters that concerned in air conditioning design such as temperature, Relative Humidity $(\mathrm{RH})$, room pressure, air cleanliness, ventilation and room air distribution. Cooling Load Temperature Difference (CLTD) will be the main method in this research. Meanwhile, Equal Friction Loss method will be used in air duct sizing. From calculation, obtained that cooling load capacity 8,805 kW. Meanwhile heating capacity obtained 3,660 kW. Total pressure loss value for design air duct is 44,85 Pa.. Pre-filter and medium filter was built-in at AC unit, so HEPA filter is needed to be mounted in ceiling.
\end{abstract}

Keywords: Air Conditioning System, NICU, HAIs, CLTD

\section{PENDAhULUAN}

Hospital-acquired infections (HAIs, atau yang biasa disebut dengan infeksi nosokomial) menjadi salah satu masalah serius yang terjadi di rumah sakit. HAIs menyebar melalui kontak secara langsung maupun tidak langsung (Hemavathy, Bhaskaran and Sudha, 2016). Sebagian besar gejala infeksi nosokomial timbul saat masih dirawat di rumah sakit namun ada pula penyakit yang muncul setelah pasien pulang (Soleha TU, Rukmono P, 2015). Salah satu media yang menjadi penyebaran HAIs adalah udara. Menurut ASHRAE HVAC Design Manual for Hospital and Clinics, untuk mencegah penyebaran penyakit melalui udara, maka diperlukan sistem tata udara yang khusus. Parameter-parameter yang perlu dikondisikan dalam sistem tata udara yaitu suhu, kelembaban udara relatif, tekanan ruangan, 
kebersihan udara, ventilasi, distribusi udara pada ruangan.

Oleh karenanya, penggunaan alat penyegar udara standar di ruang NICU, tidak direkomendasikan. Hal ini disebabkan oleh fungsi dari alat penyegar udara standar tersebut hanya dapat mengendalikan suhu ruangan. Sedangkan untuk mencapai kenyamanan termal dan kesehatan, terdapat rentang kelembaban relatif udara untuk pengendalian infeksi dan hidupnya microorganisme. Meskipun tubuh manusia umumnya dapat bertahan pada variasi $\mathrm{RH}$ dari $35 \%$ hingga $75 \%$, namun kondisi yang terlalu kering dan terlalu lembab dapat mengganggu kenyamanan. Dalam perancangan sistem tata udara, maksimum $60 \%$ RH umumnya dapat digunakan untuk kondisi kenyamanan thermal dan mengurangi resiko pertumbuhan jamur dan debu tungau (Koenigshofer, 2013). Udara yang terlalu kering menyebabkan keringnya lapisan mukosa dan dapat menyebabkan infeksi saluran pernapasan akut. Udara yang terlalu lembab dapat dapat menyebabkan tumbuhnya bermacammacam jamur dan spora (Jayanti dkk, 2016). Oleh karenanya, diperlukan electric heater untuk mengatur RH dalam ruangan.

Dalam memilih alat penyegar udara, diperlukan perhitungan kapasitas pendinginan yang berfungsi untuk menghitung kalor yang harus ditangani oleh peralatan pengondisian udara dalam mempertahankan kondisi nyaman pada ruangan tertentu. Perhitungan kapasitas pendinginan ini berdasar pada buku Cooling Load Calculation Manual yang diterbitkan oleh ASHRAE (American Society of Heating, Refrigerating and Air-Conditioning Engineers). Perhitungan kapasitas pendinginan yang berkaitan dengan kondisi lingkungan yang mendekati harga ekstrim yang biasa ditemui, didasarkan pada kondisi puncak.

Hal lain yang perlu diperhatikan adalah sistem ventilasi yang berkaitan dengan tekanan udara. Tekanan udara antara ruang NICU dengan ruangan lain di sekitarnya, perlu direncanakan agar udara yang mengandung penyakit dari suatu ruangan tidak menyebar ke ruangan-ruangan sekitarnya. Sesuai dengan fungsinya, beberapa ruangan memerlukan tekanan ruangan yang positif atau negatif terhadap ruangan sekitarnya. Gambar 1 menunjukkan rangkaian ruangan yang memerlukan tekanan positif atau negatif, relatif terhadap ruangan di sekitarnya.

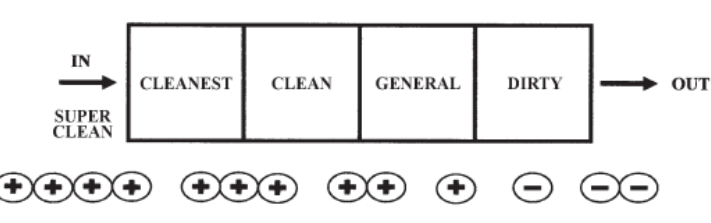

Gambar 1. Pengkondisian Pergerakan Udara melalui Pressure Relationships (Koenigshofer, 2013)

Perencanaan ventilasi berkaitan dengan distribusi/pergerakan aliran udara. Aliran udara seringkali sulit dikontrol karena efek bukaan pintu, gerakan petugas dan pasien, perbedaan suhu. Pada beberapa fungsi bangunan, minimum Air Change per Hour $(\mathrm{ACH})$ digunakan untuk mencegah penyebaran penyakit (Azimi and Stephens, 2013). Air Change per Hour juga digunakan untuk mengurangi waktu paparan yang disebabkan oleh microorganisme melalui benda-benda, staff maupun pasien dalam ruangan (Koenigshofer, 2013). Pergantian udara yang tinggi juga dapat memperepat dilusi pathogen dan mengurangi resiko infeksi yang ditransmisikan melalui udara (Sundari et al., 2017).

Ruang perawatan NICU, merupakan ruangan khusus untuk merawat bayi baru lahir yang mengalami masalah kesehatan. Pada ruang NICU, perlu dipasang HEPA Filter pada keluaran diffuser, setelah udara dari luar dan udara resirkulasi tercampur (Licina et al., 2016).

Grille return dan exhaust dapat diletakkan di ceiling. Namun, untuk peletakan grille di bawah, dapat membuat laju aliran udara menjadi laminer. Syarat untuk udara laminer adalah memiliki bilangan Reynold $<2100$. Penentuan ukuran grille return dan exhaust dapat berdasarkan core velocity sebessar 1,5 hingga 2,5 m/s untuk mengendalikan kebisingan dan mengurangi pressure drop (Koenigshofer, 2013). Selain itu, letak kasur untuk pasien perlu diletakkan dekat dengan return grille (Abduladheem et al., 2013).

Tingkat kebersihan pada ruangan NICU dapat dikondisikan dengan menggunakan filter udara. ANSI/ASHRAE Standard 52.2-2007 (ASHRAE 2007) menetapkan prosedur pengetesan untuk mengevaluasi performansi peralatan filter udara. Hasil dari pengetesan tersebut adalah MERV (Minimum Efficiency Reporting Value). Tabel 1 merupakan nilai MERV dan efisiensi filter berdasarkan ukuran partikel.

Berdasarkan fungsi dari ruangan yang akan di filtrasi, terdapat syarat-syarat penggunakan prefiltration dan final filtration. 
Tabel 1. MERV dan Efisiensi Filter berdasarkan Ukuran Partikel (Koenigshofer, 2013)

\begin{tabular}{|c|c|c|c|}
\hline MERV & $\mathbf{0 . 3 - 1 . 0} \boldsymbol{\mu m}$ & $\mathbf{1 . 0 - 3 . 0} \boldsymbol{\mu m}$ & $\mathbf{3 . 0 - 1 0} \boldsymbol{\mu m}$ \\
\hline Category E-3 & & & \\
\hline 6 & - & - & 35 to $50 \%$ \\
\hline 7 & - & - & 50 to $70 \%$ \\
\hline 8 & - & - & 70 to $85 \%$ \\
\hline 9 & - & - & $85 \%+$ \\
\hline Category E-2 & - & & \\
\hline 10 & - & 60 to $65 \%$ & $85 \%+$ \\
\hline 11 & & $80 \%+$ & $85 \%+$ \\
\hline 12 & $<75 \%$ & $90 \%+$ & $95 \%+$ \\
\hline Category E-1 & 75 to $85 \%$ & $90 \%+$ & $99 \%+$ \\
\hline 13 & 85 to $95 \%$ & $90 \%+$ & $99 \%+$ \\
\hline 14 & $99 \%$ & $99 \%$ & $99 \%$ \\
\hline 15 & & & \\
\hline 17 & & & \\
\hline
\end{tabular}

Source: Adapted from ANSI/ASHRAE Standard 52.2-2007 (ASHRAE 2007).

Tabel 2. Nilai Efisiensi Filter Minimal

(Koenigshofer, 2013)

\begin{tabular}{|c|c|c|}
\hline Space Designation (According to Function) & $\begin{array}{l}\text { Filter Bank } \\
\text { No. 1, } \\
\text { MERV }\end{array}$ & $\begin{array}{l}\text { Filter Bank } \\
\text { No. 2, } \\
\text { MERV }\end{array}$ \\
\hline $\begin{array}{l}\text { Classes } B \text { and } C \text { surgery; inpatient and ambulatory diagnostic and } \\
\text { therapeutic radiology; inpatient delivery and recovery spaces }\end{array}$ & 7 & 14 \\
\hline $\begin{array}{l}\text { Inpatient care, treatment and diagnosis, and those spaces providing direct } \\
\text { service or clean supplies and clean processing (except as noted below); } \\
\text { AII (rooms) }\end{array}$ & 7 & 14 \\
\hline Protective environment rooms (PE) & 7 & $17(\mathrm{HEPA})^{\mathrm{c}}$ \\
\hline Laboratories; Class A surgery and associated semirestricted spaces & $13^{\mathrm{b}}$ & $N / R^{d}$ \\
\hline $\begin{array}{l}\text { Administrative; bulk storage, soiled holding spaces; food preparation } \\
\text { spaces; and laundries }\end{array}$ & 7 & $N / R$ \\
\hline All other outpatient spaces & 7 & $N / R$ \\
\hline Skilled nurses facilities & 7 & $\mathrm{~N} / \mathrm{R}$ \\
\hline \multicolumn{3}{|l|}{ Source: ASHRAE (2008). } \\
\hline \multicolumn{3}{|c|}{$\begin{array}{l}\text { Notes: } \\
\text { a. Minimum efficiency reporting value (MERV) is based on method of testing described in ANSI/ASHRAE } \\
\text { Standard } 52.2-2007 \text {. } \\
\text { b. Additional prefilters may be used to reduce maintenance for filters with efficiencies higher than MERV } 7 \text {. } \\
\text { c. Filter Bank } \# 2 \text { may be MERV } 14 \text { if MERV } 17 \text { tertiary terminal filter is provided for these spaces. } \\
\text { d. N/R = not required. }\end{array}$} \\
\hline
\end{tabular}

Perancangan sistem distribusi udara (air duct) untuk sistem tata udara dapat dilakukan setelah kalor yang dihasilkan oleh total ruangan dan supply udara ruangan telah dihitung. Distribusi udara yang baik akan mempengaruhi tingkat kenyamanan penghuni. Oleh karenanya, dalam merancang saluran distribusi udara, terdapat beberapa parameter yang perlu diperhatikan yaitu penurunan tekanan pada saluran udara lurus (major losses) dan penurunan tekanan udara pada sambungan (minor losses) (Wang, 2000).

Dalam merancang air duct dengan ukuran persegi, terdapat aspect ratio yang direkomendasikan, yaitu mendekati $1: 1$, untuk mengurangi friction loss dan berpengaruh terhadap biaya yang digunakan. Semakin besar aspect ratio, semakin besar ketebalan metal yang akan digunakan, juga semakin berat air duct yang terpasang. Yang berakibat pada penambahan biaya yang digunakan. Untuk design air velocity yang digunakan adalah maksimal $15 \mathrm{~m} / \mathrm{s}$ di main duct (Wang, 2000).

Pada penelitian ini akan dipaparkan bagaimana merancang sistem tata udara untuk ruang NICU dengan mempertimbangkan parameter-parameter yang perlu diperhatikan dalam perancangan sistem tata udara untuk mengurangi resiko HAIs.

\section{METODE}

\section{Tahapan Penelitian}

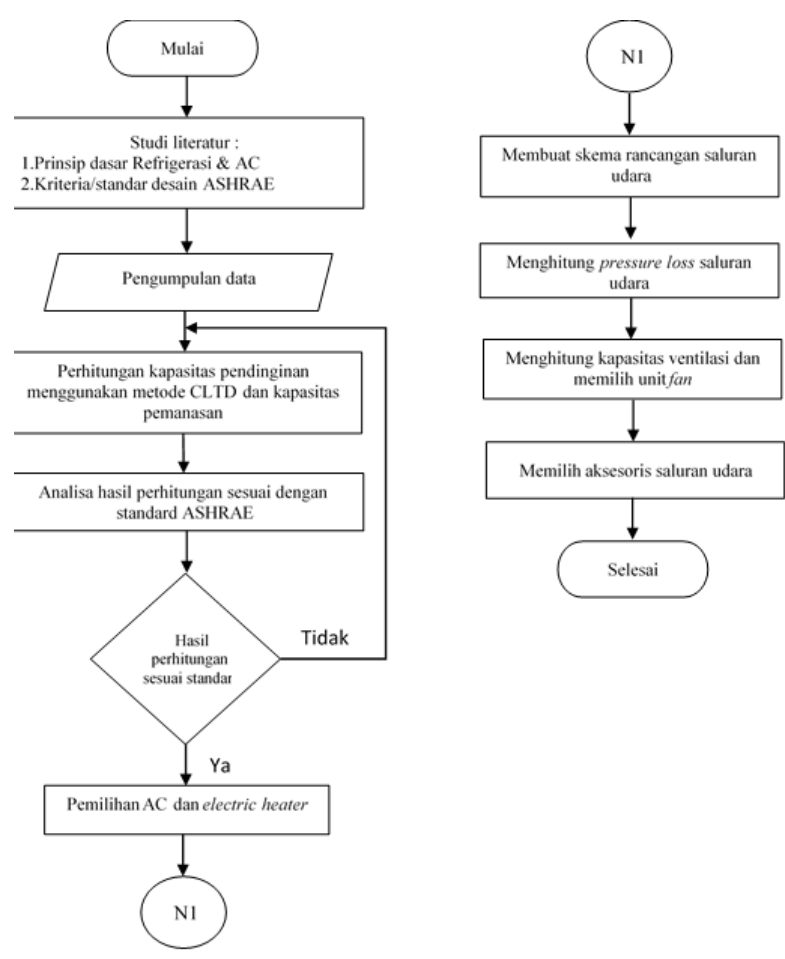

Gambar 2. Tahapan Penelitian

1. Studi literatur dilakukan untuk mencari dasardasar teori dan perhitungan yang digunakan. yaitu dasar teori sistem tata udara dan kriteria/standar desain sistem tata udara pada ruang NICU.

2. Data yang dikumpulkan berupa gambar, ukuran ruangan, fungsi ruangan, desain temperatur udara luar dan parameter desain dari ruangan yang akan dikondisikan.

3. Perhitungan dan analisa hasil perhitungan terdiri dari perhitungan beban pendinginan, yang dilakukan dengan metode CLTD (Cooling Load Temperature Difference). Beban pemanasan akan dilakukan analisis psikrometrik. Hasil perhitungan akan dianalisa apakah sesuai dengan ASHRAE check figure table. 
4. Seleksi peralatan AC dilakukan secara manual menggunakan katalog.

5. Pembuatan skema rancangan saluran udara dapat mempermudah untuk perhitungan pressure loss air duct.

6. Menghitung pressure loss air duct baik dari saluran lurus maupun sambungan.

7. Menghitung kapasitas ventilasi dan unitnya diseleksi secara manual menggunakan katalog product.

8. Memilih aksesoris saluran udara seperti diffuser, grille, louvre, dan filter.

9. Kesimpulan yang merupakan hasil akhir yang diperoleh dari penelitian yang dilakukan.

\section{Gambar Struktur dan Dimensi Bangunan}

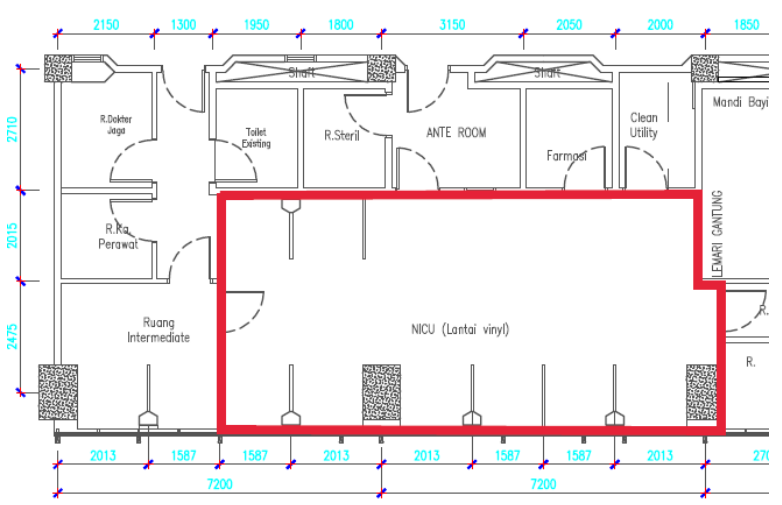

Gambar 3. Gambar Layout Ruang NICU

Dari gambar struktur tersebut, didapat dimensi ruangan yang akan dikondisikan :

Panjang Ruangan : 10,8 m

Lebar Ruangan $\quad: 5,47 \mathrm{~m}$

Tinggi Ceiling $: 3,5 \mathrm{~m}$

Elevasi $\quad: 10,5 \mathrm{~m}$

\section{Parameter Rancangan Sistem Tata Udara}

Parameter sistem tata udara yang akan dirancang mengacu dari Tabel 3 pada ASHRAE Handbook 2009, Ventilation Requirements for Areas Affecting Patient Care in Hospital and Outpatient Facilities. Berdasarkan fungsi ruangan, maka didapat parameter rancangan sistem tata udara untuk ruang NICU sebagai berikut:

$\begin{array}{ll}\text { Temperatur Rancangan } & : 22^{\circ} \mathrm{C} \\ \text { RH Rancangan } & : 50 \% \\ \text { Tekanan Udara Rancangan } & :+5 \sim+10 \mathrm{~Pa} \\ \text { Min. ACH Total } & : 6 \\ \text { Min. ACH OA } & : 2\end{array}$

\section{Kondisi Lingkungan}

Sebelum menghitung kapasitas pendinginan, diperlukan data kondisi lingkungan, dengan bulan terpanas adalah pada bulan November.
1. Lokasi
$=$ Jakarta

2. Letak geografis $=5^{\circ} 19^{\prime} 12^{\prime \prime}-6^{\circ} 23^{\prime} 54^{\prime \prime} \mathrm{LS}$

3. Arah bangunan = Menghadap utara

4. Kelembaban relatif $=60 \%$

5. Temp. ambient, $\max =35^{\circ} \mathrm{C}$

Temperatur ambient yang digunakan pada perhitungan adalah temperatur ambient rata-rata menggunakan rumus (1) sebagai berikut.

$$
T_{o}=T_{o, \max }-\frac{d r}{2}
$$

Dimana nilai :

$T_{o}$ (temp. ambient rata-rata) $=28,5^{\circ} \mathrm{C}=83,3^{\circ} \mathrm{F}$

$T_{o, \text { max }}$ (temp. ambient maksimal $)=35^{\circ} \mathrm{C}$

$d r$ (daily range, selisih $T_{o, \text { max }}$ dan $\left.T_{o, \text { min }}\right)=13^{\circ} \mathrm{C}$

\section{Kondisi Konstruksi Bangunan}

Kondisi konstruksi bangunan diperlukan untuk mengetahui nilai koefisien perpindahan panas (U).

Nilai $\mathrm{R}$ dan $\mathrm{SH} \times \mathrm{WT}$ material dapat dilihat pada tabel 3.11 ASHRAE GRP 158 Cooling Load and Heating Load Calculation Manual. Nilai U dapat dicari dengan menjumlahkan nilai resistansi thermal $\left(R_{t}\right)$ dengan persamaan (2) dan (3) sebagai berikut.

$$
U=\frac{1}{R_{t}}
$$

Keterangan :

$U=$ Koefisien perpindahan panas (BTU/hr. $\left.\mathrm{ft}^{2}{ }^{\circ}{ }^{\circ} \mathrm{F}\right)$ $R_{t}=$ Nilai total penjumlahan resistansi thermal (hr.ft $\left.{ }^{2}{ }^{\circ} \mathrm{F} / \mathrm{BTU}\right)$

$$
R_{t}=R_{1}+R_{2}+R_{n}
$$

Keterangan :

$R_{t}=$ Nilai total penjumlahan resistansi thermal (hr.ft ${ }^{2} .{ }^{\circ} \mathrm{F} / \mathrm{BTU}$ )

$R_{1}, R_{2}, R_{n}=$ Nilai resistansi thermal lapisan 1,2 , hingga lapisan $n$ (hr. $\left.\mathrm{ft}^{2} .{ }^{\circ} \mathrm{F} / \mathrm{BTU}\right)$

Nilai $\mathrm{U}$ dan $\mathrm{SH} \times \mathrm{WT}$ digunakan untuk menentukan grup dinding, yang klasifikasinya terdapat pada tabel 3.9 ASHRAE GRP 158 Cooling Load and Heating Load Calculation Manual. 


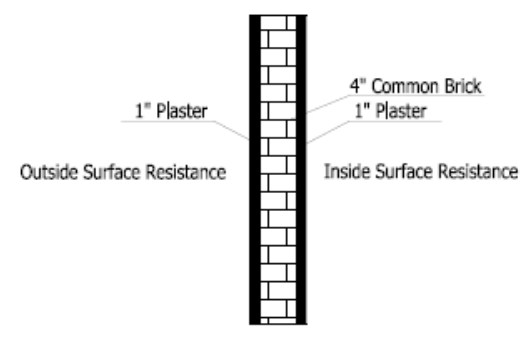

Gambar 4. Ilustrasi Lapisan Dinding Luar dan Partisi

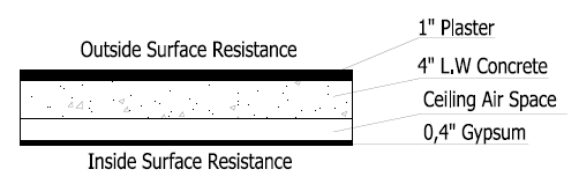

Gambar 5. Ilustrasi Lapisan Atap

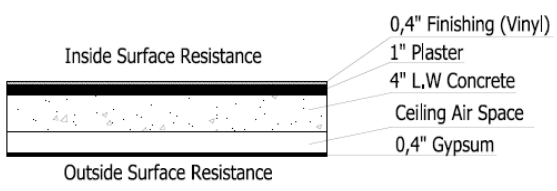

Gambar 6. Ilustrasi Lapisan Lantai

Kalor yang dihasilkan oleh Internal Ruangan

- Daftar Peralatan

Peralatan medis dan elektronik yang menghasilkan panas sensibel, nilai konsumsi daya rata-rata dapat dilihat pada tabel 6 dan tabel 8 pada ASHRAE handbook 2009 chapter 18 mengenai Non-Residential Cooling.

Tabel 3. Daftar Peralatan di Ruang NICU

\begin{tabular}{|c|c|c|c|}
\hline $\begin{array}{c}\text { Nama } \\
\text { Peralatan }\end{array}$ & Jumlah & $\begin{array}{c}\text { Konsumsi } \\
\text { Daya Rata- } \\
\text { Rata (Watt) }\end{array}$ & $\begin{array}{c}\text { Daya Total } \\
\text { (Watt) }\end{array}$ \\
\hline Ventilator & 5 & 125 & 750 \\
\hline Monitor & 8 & 80 & 640 \\
\hline Komputer & 1 & 73 & 73 \\
\hline
\end{tabular}

- Daftar Alat Penerangan

Peralatan penerangan pada ruang NICU berdasarkan gambar rancangan instalasi elektrikal.

Tabel 4. Daftar Alat Penerangan di Ruang NICU

\begin{tabular}{|c|c|c|c|}
\hline $\begin{array}{c}\text { Jenis } \\
\text { Lampu }\end{array}$ & $\begin{array}{c}\text { Daya } \\
\text { Setiap } \\
\text { Lampu } \\
\text { (Watt) }\end{array}$ & $\begin{array}{c}\text { Jumlah } \\
\text { Lampu }\end{array}$ & $\begin{array}{c}\text { Total Daya } \\
\text { Penerangan } \\
\text { (Watt) }\end{array}$ \\
\hline $\begin{array}{c}\text { Exam Light } \\
\text { TLD (3x18 } \\
\text { Watt) }\end{array}$ & 54 & 8 & 432 \\
\hline $\begin{array}{c}\text { Down Light } \\
\text { LED 7 Watt }\end{array}$ & 7 & 11 & 77 \\
\hline
\end{tabular}

\section{- Jumlah Penghuni}

Jumlah penghuni pada ruang NICU adalah 11 orang.

\section{Duct Sizing Menggunakan Aplikasi Duct Sizer}

Dalam menentukan dimensi air duct digunakan metode Equal Friction. Nilai yang direkomendasikan adalah 0,8 hingga 1 $\mathrm{Pa} / \mathrm{m}$ (Wang, 2000). Oleh karenanya, dalam menentukan dimensi $\mathrm{H} \times \mathrm{W}$ (Height $\times$ Width, atau Tinggi $\times$ Lebar), digunakan software Duct Sizer yang dikeluarkan oleh McQuay International.

Dengan menggunakan metode Equal Friction, maka parameter yang menjadi input adalah Flow Rate dan Head Loss. Nilai kecepatan dan ukuran air duct akan didapatkan yang kemudian digunakan untuk menghitung pressure loss.

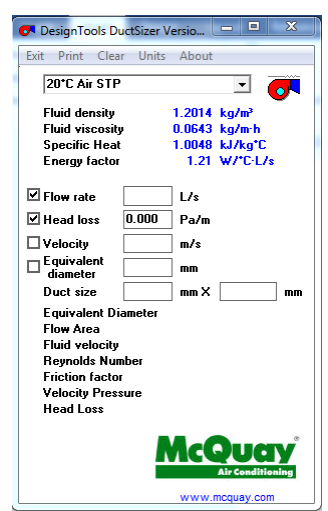

Gambar 7. Tampilan software Duct Sizer by McQuay International

\section{Perhitungan Pressure Loss pada Air Duct}

Nilai pressure loss pada saluran udara lurus (Major Losses) dapat dihitung menggunakan persamaan Darcy and Colebrook.

$$
\Delta P_{f}=\frac{f L}{D_{e}} \times \frac{\rho v^{2}}{2 g}
$$

Keterangan :

$\Delta \mathrm{P}_{f} \quad=$ Friction loss $/$ Major Losses $(\mathrm{Pa})$

$f \quad=$ friction factor, dilihat pada diagram Moody

$L \quad=$ Panjang saluran air duct $(\mathrm{m})$

$D_{e} \quad=$ Diameter equivalent $(\mathrm{m})$

$v \quad=\operatorname{Kecepatan}(\mathrm{m} / \mathrm{s})$

$\rho \quad=$ Density $\left(\mathrm{kg} / \mathrm{m}^{3}\right)$

Sedangkan untuk menghitung diameter equivalent, persamaan yang digunakan yaitu persamaan berikut. 


$$
D_{e}=\frac{1,3(a \times b)^{0,625}}{(a+b)^{0,25}}
$$

Keterangan :

$D_{e} \quad=$ Diameter equivalent $(\mathrm{mm})$

$a, b=$ Dimensi 2 sisi air duct $(\mathrm{mm})$

Nilai penurunan tekanan pada sambungan air duct (Minor Losses) didapat menggunakan persamaan sebagai berikut.

$$
P_{v}=0,602 \times v^{2}
$$

Keterangan :

$$
\begin{array}{ll}
P_{v} & =\text { Tekanan akibat aliran kecepatan }(\mathrm{Pa}) \\
v & =\text { Kecepatan udara dalam saluran }(\mathrm{m} / \mathrm{s})
\end{array}
$$

Nilai penurunan tekanan total didapat dari penjumlahan dari rugi tekanan pada saluran lurus (Major Losses) dengan rugi tekanan pada sambungan (Minor Losses).

\section{HASIL DAN PEMBAHASAN}

Setelah semua data terkumpul dan kapasitas pendinginan dihitung, didapat jam beban puncak yang ditentukan berdasarkan nilai kapasitas pendinginan terbesar. Jam beban puncak untuk ruang NICU adalah pukul 16:00.

\section{Nilai U Konstruksi Bangunan}

Setelah dilakukan perhitungan untuk dinding luar, dinding partisi, atap dan lantai, berikut adalah nilai U masing-masing konstruksi:

$$
\begin{aligned}
& \text { Dinding luar dan partisi } \\
& \begin{array}{ll}
\mathrm{U} & =0,46 \mathrm{BTU} / \mathrm{hr}_{\mathrm{ft}}{ }^{2} .{ }^{\circ} \mathrm{F} \\
\text { Grup Dinding } & =\mathrm{D}
\end{array}
\end{aligned}
$$

\section{Atap}

$$
\begin{array}{ll}
\mathrm{U} & =0,14 \mathrm{BTU} / \mathrm{hr}_{\mathrm{U}} \mathrm{ft}^{2}{ }^{\circ} \mathrm{F} \\
\text { Nomor Atap } & =3
\end{array}
$$

Lantai

$$
\mathrm{U} \quad=0,14 \mathrm{BTU} / \mathrm{hr} . \mathrm{ft}^{2}{ }^{\circ} \mathrm{F}
$$

\section{Perhitungan Kapasitas Pendinginan}

Jenis-jenis kalor yang dihasilkan dalam menghitung kapasitas pendinginan terbagi atas 3 bagian besar :
a. Kalor yang dihasilkan oleh dinding luar, dinding partisi, atap, kaca, pintu dan atap (Eksternal).
b. Kalor yang ditimbulkan oleh manusia, penerangan, peralatan (Internal), dan

c. Kalor akibat dari ventilasi dan infiltrasi (Irfan, Syed Faheem; Syed, Mujeeb Ali; Syed
Suleman; Syed, Obaid Ur Rahman; Syed, 2017).

Rumus perhitungan kalor mengacu pada buku Cooling and Heating Load Calculation Manual. ASHRAE, 1980 (ASHRAE GRP 158 Cooling Load and Heating Load Calculation Manual).

\section{Perpindahan Kalor yang Berasal dari Luar} (External)

\section{- Kalor yang Dihasilkan Dinding Luar \\ $\left(\mathbf{Q}_{\text {wall,ex }}\right)$}

Sebelum menghitung kalor yang dihasilkan oleh dinding luar yang terkena sinar matahari langsung pada ruang NICU, perlu dihitung nilai $C L T D_{\text {corr }}$ menggunakan persamaan berikut.

$$
\text { CLTD }_{\text {corr }}=C L T D+L M \times K+\left(78-T_{r}\right)+\left(T_{o}-85\right)
$$

Dimana nilai :

$$
\begin{array}{ll}
\text { CLTD } & =33 \\
\text { LM }(\text { Latitude Month }) & =-3 \\
K(\text { Koefisien warna dinding }) & =0,65 \\
T_{r}(\text { Temp. Ruangan Rancangan }) & =69,2 \\
{ }^{\circ} \mathrm{F} & =83,3^{\circ} \mathrm{F} \\
T_{o}(\text { Temp. Udara Luar }) & =26,6^{\circ} \mathrm{F}
\end{array}
$$

Nilai CLTD didapat dari tabel 3.10 sedangkan LM dan K didapat dari tabel 3.12 ASHRAE GRP 158 Cooling Load and Heating Load Calculation Manual. Sedangkan nilai kalor yang dihasilkan oleh dinding luar dapat dihitung menggunakan persamaan :

$$
Q_{\text {wall }, \text { ex }}=\frac{U_{\text {wall,ex }} \times A_{\text {wall,ex }} \times C L T D_{\text {corr }}}{3,412}
$$

Keterangan :

$Q_{\text {wall,ex }}$ (Kalor dinding luar) $=4,976$ Watt

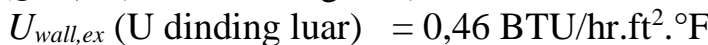

$A_{\text {wall,ex }}$ (Luas dinding luar) $\quad=406,67 \mathrm{ft}^{2}$

$C_{\text {corr }} \quad=26,6^{\circ} \mathrm{F}$

3,412 (konversi satuan ke SI)

\section{- Kalor yang Dihasilkan Dinding Partisi $\left(\mathbf{Q}_{\text {wall,in }}\right)$}

Kalor yang dihasilkan oleh dinding partisi bagian barat dapat dihitung menggunakan persamaan berikut. 


$$
Q_{\text {wall,in }}=\frac{U_{\text {wall,in }} \times A_{\text {wall,in }} \times T D}{3,412}
$$

Dimana nilai :

$Q_{\text {wall, in }}($ Kalor dinding partisi $)=42,05$ Watt

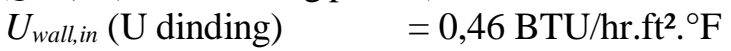

$A_{\text {wall, } \text {, }}$ (Luas dinding) $\quad=174,3 \mathrm{ft}^{2}$

$T D$ (Beda temperatur) $\quad=1,8^{\circ} \mathrm{F}$

3,412 (konversi satuan ke SI)

Dengan menggunakan persamaan yang sama, didapat nilai kalor untuk dinding partisi lainnya.

Dinding Selatan dan Utara

$Q_{\text {wall } \text { in }}$ (Kalor dinding partisi $)=282,51$ Watt

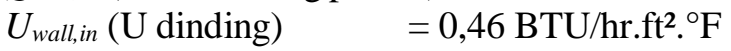

$A_{\text {wall, in }}$ (Luas dinding) $\quad=180,1 \mathrm{ft}^{2}$

$T D$ (Beda temperatur) $\quad=11,7^{\circ} \mathrm{F}$

3,412 (konversi satuan ke SI)

\section{- Kalor yang Dihasilkan Atap $\left(\mathbf{Q}_{\text {roof }}\right)$}

Kalor yang dihasilkan oleh atap yang tidak terkena sinar matahari langsung dapat dihitung secara konduksi dengan menggunakan persamaan berikut.

$$
Q r_{\text {oof }}=\frac{U_{\text {roof }} \times A_{\text {roof }} \times T D}{3,412}
$$

Dimana nilai :

$Q_{\text {roof }}($ Kalor Atap $) \quad=302,35 \mathrm{Watt}$

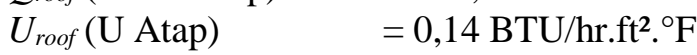

$A_{\text {roof }}\left(\right.$ Luas atap) $\quad=635,6 \mathrm{ft}^{2}$

$T D$ (Beda temperatur) $=11,7^{\circ} \mathrm{F}$

3,412 (konversi satuan ke SI)

\section{- Kalor yang Dihasilkan Lantai $\left(\mathbf{Q}_{\text {floor }}\right)$}

Kalor yang dihasilkan oleh lantai dapat dihitung secara konduksi dengan menggunakan persamaan berikut.

$$
Q_{\text {floor }}=\frac{U_{\text {floor }} \times A_{\text {floor }} \times T D}{3,412}
$$

Dimana nilai :

$Q_{\text {floor }}($ Kalor Lantai $) \quad=302,35 \mathrm{Watt}$

$U_{\text {roof }}\left(\mathrm{U}\right.$ Latai) $\quad=0,14 \mathrm{BTU} / \mathrm{hr} . \mathrm{ft}^{2} .{ }^{\circ} \mathrm{F}$

$A_{\text {roof }}($ Luas Lantai $) \quad=635,6 \mathrm{ft}^{2}$

$T D$ (Beda temperatur) $\quad=11,7^{\circ} \mathrm{F}$

3,412 (konversi satuan ke SI)
Perpindahan Kalor yang Berasal dari Internal

- Kalor yang Dihasilkan oleh Penghuni $\left(\mathbf{Q}_{\text {person }}\right)$

Kalor sensibel dan laten yang dihasilkan manusia dihitung menggunakan persamaan sebagai berikut.

$$
\begin{aligned}
Q_{\text {person,sensible }} & =\frac{q s / p \times n \times C L F}{3,412} \\
Q_{\text {person,latent }} & =\frac{q l / p^{\times n}}{3,412}
\end{aligned}
$$

Dimana nilai :

$Q_{\text {person,sensible }}$ (Kalor sensibel manusia) $=609,32$ Watt

$Q_{\text {person,latent }}$ (Kalor laten oleh manusia) $=451,34$

Watt

$q_{s} p$ (Kalor sensibel per orang per jam $)=210$ $\mathrm{BTU} / \mathrm{hr}$

$q \downarrow p$ (Kalor laten per orang per jam) $\quad=140$

BTU/hr

$n$ (jumlah orang) $\quad=11$

orang

CLF ( Cooling Load Factor $) \quad=0,9$

Kalor per orang $\left(\mathrm{q}_{\mathrm{s}} / \mathrm{p} \& \mathrm{q} / \mathrm{p}\right)$ diperoleh dari Tabel 4.5 pada buku ASHRAE GRP 158 Cooling Load and Heating Load Calculation Manual. Jam operasional untuk ruang NICU diasumsikan 24 jam. Sehingga nilai CLF untuk penghuni ruang NICU dilihat pada tabel 4.6 pada buku ASHRAE GRP 158 Cooling Load and Heating Load Calculation Manual adalah 0,9.

\section{- Kalor yang Dihasilkan oleh Peralatan Penerangan $\left(\mathbf{Q}_{\text {lights }}\right)$}

Kalor yang dihasilkan oleh peralatan penerangan dihitung menggunakan rumus sebagai berikut.

$$
Q_{\text {lights }}=q \times F_{u} \times F_{s} \times C L F
$$

Dimana nilai :

$Q_{\text {lights }}($ Kalor dari peralatan penerangan $)=661,7$ Watt

$Q$ (Daya total dari lampu $=509 \mathrm{Watt}$

$F_{u}$ (Faktor dari lampu yang menyala) $=1$

$F_{s}($ Factor Ballast $) \quad=1,3$

CLF (Cooling Load Factor) $\quad=1$

Lampu pada ruangan NICU menyala ketika sistem pendingin menyala sehingga lampu menyala selama 24 jam. Nilai CLF dengan kondisi 
tersebut adalah 1. Total lampu yang digunakan, yaitu semua lampu. Sehingga $F_{u}=1$. Sedangkan lampu yang digunakan per armatur adalah 1 dengan daya lampu tidak lebih dari 60 Watt sehingga pada Tabel 4.14 pada buku ASHRAE GRP 158 Cooling Load and Heating Load Calculation Manual, diperoleh nilai Fs = 1,3.

\section{- Kalor yang Dihasilkan oleh Peralatan Elektronik ( $\left.\mathbf{Q}_{\text {equipment }}\right)$}

Kalor yang dihasilkan oleh peralatan elektronik secara sensibel dan laten dihitung menggunakan rumus sebagai berikut.

$$
\begin{gathered}
Q_{\text {equip,sensible }}=C_{s} \times Q \times C L F \\
Q_{\text {equip,latent }}=C_{l} \times Q
\end{gathered}
$$

Dimana nilai :

$Q_{\text {equip,sensible }}($ Kalor sensibel peralatan) $=649,09$ Watt

$Q_{\text {equip,latent }}($ Kalor laten peralatan $)=254,66$ Watt

$C_{s}$ (Coefficient Sensible $) \quad=0,33$

$Q$ (Manufacture's Input Rating) $=2138 \mathrm{Watt}$

$Q$ (Manufacture's Input Rating) Laten $=1498$ Watt

CLF (Cooling Load Factor) $\quad=0,92$

Diketahui alat penyegar udara di dalam ruangan NICU beroperasi selama 24 jam. Sehingga nilai CLF terdapat pada tabel 4.11 buku ASHRAE GRP 158 Cooling Load and Heating Load Calculation Manual.

\section{Perpindahan Kalor akibat Infiltrasi}

Infiltrasi merupakan aliran udara luar yang memasuki ruangan melalui celah dan bukaan lainnya yang tidak disengaja (Rudoy, 1980). Kalor yang ditimbulkan oleh infiltrasi dapat dihitung dengan menggunakan persamaan berikut.

$$
\begin{aligned}
& Q_{\text {inf, }, \text { sensible }}=1,23 \times \Delta T \times V_{\mathrm{inf}} \\
& Q_{\text {inf, } \text { latent }}=3,01 \times \Delta \omega \times V_{\mathrm{inf}}
\end{aligned}
$$

Dimana nilai :

$Q_{\text {inf,sensible }}($ Kalor infiltrasi sensibel) $\quad=183,69$ Watt

$Q_{\text {inf,latent }}($ Kalor infiltrasi laten $)=673,59 \mathrm{Watt}$

$\Delta T$ (Perbedaan temperatur) $\quad=6,5^{\circ} \mathrm{C}$

$\Delta \omega$ (Perbedaan rasio kelembaban) $=9,74 \mathrm{~g}_{\mathrm{v}} / \mathrm{kg}_{\mathrm{a}}$

$V_{\text {inf }}($ Debit udara infiltrasi) $\quad=22,98 \mathrm{~L} / \mathrm{s}$

Debit infiltrasi untuk ruang isolasi negatif dapat dihitung dengan menggunakan rumus berikut. Nilai ACH infiltrasi dapat digunakan 0,15 hingga
0,4 (Wang, 2000). ACH yang digunakan dalam perhitungan ini adalah 0,4 .

$$
V_{\text {inf, sensible }}=A C H \times V o l
$$

Dimana nilai :

$V_{\text {inf }}$ (Debit udara infiltrasi) $=22,98$ Liter/detik

ACH (Air Change per Hour) $=0,4$

$\mathrm{Vol}($ Volume ruangan $) \quad=206,77 \mathrm{~m}^{3}$

Untuk mengubah satuan dari $\mathrm{m}^{3} / \mathrm{h}$ menjadi Liter/detik, maka hasil perhitungan tersebut dikalikan dengan nilai 0,2778 . Sedangkan nilai rasio kelembaban ditentukan menggunakan Diagram Psikrometrik. Diperlukan 2 parameter untuk menentukan rasio kelembaban. Untuk menentukan rasio kelembaban ruangan maka gunakan temperatur rancangan $22^{\circ} \mathrm{C}$ dan $\mathrm{RH}$ rancangan $50 \%$. Sehingga didapat rasio kelembaban ruangan sebesar $5 \mathrm{~g}_{\mathrm{v}} / \mathrm{kg}_{\mathrm{a}}$. Sedangkan untuk rasio kelembaban udara luar menggunakan nilai temperatur udara luar rata-rata $28,5^{\circ} \mathrm{C}$ dengan kelembaban maksimal $60 \%$, maka didapat nilai rasio kelembaban udara luar $\left(\omega_{o}\right)$ sebesar 14,74 $\mathrm{g}_{\mathrm{v}} / \mathrm{kg}_{\mathrm{a}}$.

\section{Perpindahan Kalor akibat Ventilasi}

Perhitungan kalor yang dihasilkan oleh ventilasi diperlukan untuk menentukan $O A S H$ (Outside Air Sensible Heat) dan OALH (Outside Air Latent Heat) yang dibutuhkan pada analisis psikometrik. Nilai $O A S H$ dan $O A L H$ diperoleh menggunakan rumus berikut.

$$
\begin{aligned}
& O A S H=1,23 \times \Delta T \times V_{\text {vent }} \\
& O A L H=3,01 \times \Delta \omega \times V_{\text {vent }}
\end{aligned}
$$

Keterangan :

OASH $($ Kalor ventilasi sensibel $)=918,46 \mathrm{~W}$ att

$O A L H$ (Kalor vemtilasi laten) $=3.367,96 \mathrm{Watt}$

$\Delta T$ (Perbedaan temperatur udara $=6,5^{\circ} \mathrm{C}$

$\Delta \omega$ (Perbedaan rasio kelembaban) $=9,74 \mathrm{~g}_{\mathrm{v}} / \mathrm{kg}_{\mathrm{a}}$

$V_{\text {vent }}($ Debit udara ventilasi $) \quad=114,18 \mathrm{~L} / \mathrm{s}$

Debit ventilasi dapat dihitung menggunakan persamaan (19), sama halnya dengan menghitung debit infiltrasi. Namun nilai ACH didapat dari $\mathrm{ACH}$ udara luar yaitu 2. Sedangkan nilai perbedaan temperatur udara dan rasio kelembaban udara sama dengan nilai untuk menghitung kalor infiltrasi. 


\section{Kalor Total pada Ruangan}

Total kalor sensibel (RSHG/Room Sensible Heat Gain) yang dihasilkan oleh ruangan pada beban puncak, dapat dihitung menggunakan persamaan (21) sebagai berikut.

$$
\begin{gathered}
R S H G=Q_{\text {wall }, \text { ex }}+Q_{\text {wall }, \text { in }} Q_{\text {roof }}+Q_{\text {floor }} \\
+Q_{\text {pers,sensible }}+Q_{\text {lights }}+Q_{\text {equip,sens }} \\
R S H G=4,976+607,7+302,35+302,35 \\
+609,35+661,7+649,09
\end{gathered}
$$

Sehingga nilai RSHG adalah sebesar 3.137,52 Watt.

Sedangkan total kalor laten (RLHG/Room Latent Heat Gain) ruangan dapat dihitung menggunakan persamaan berikut.

$$
\begin{aligned}
& R L H G=Q_{\text {pers,latent }}+Q_{\text {equip,latent }}+Q_{\mathrm{inf}, \text { latent }} \\
& R L H G=451,34+254,66+673,59
\end{aligned}
$$

Sehingga nilai RLHG adalah sebesar 1.379,59 Watt.

Nilai total kalor ruangan dan nilai RSHF dapat dihitung menggunakan persamaan berikut.

$$
\begin{aligned}
R T H G & =R S H G+R L H G \\
R S H F & =\frac{R S H}{R S H+R L H}
\end{aligned}
$$

Dimana nilai :

$R T H G$ (Kalor Total Ruangan) $\quad=4.517,11 \mathrm{Watt}$ RSHF (Room Sensible Heat Factor $)=0,69$

Dalam menentukan Grand Total Heat (GTH) digunakan persamaan berikut.

$$
\begin{aligned}
& G S H=R S H+O A S H \\
& G L H=R L H+O A L H \\
& G T H=G S H+G L H
\end{aligned}
$$

$\mathrm{GSH}=3.137,52+918,46=4.055,98 \mathrm{Watt}$ $\mathrm{GLH}=1.379,59+3.367,96=4.747,55 \mathrm{Watt}$ $\mathrm{GTH}=4.055,98+4.747,55=8.803,53 \mathrm{Watt}$

\section{Kapasitas Electric Heater}

Electric heater berfungsi untuk menjaga $\mathrm{RH}$ ruangan. Sebelum menghitung kapasitas electric heater, udara yang di supply ke ruangan secara teoritis perlu dihitung dengan persamaan berikut.

$$
V_{s a}=\frac{R S H}{1,23 \times\left(T_{r a}-T_{l a}\right)}
$$

RSH (Kalor Total Sensibel Ruangan) $=3.137,52$ Watt

$T_{r a}($ Temp. Udara Ruangan $) \quad=21^{\circ} \mathrm{C}$

$T_{l a}($ Temp. Udara Keluaran Koil $)=15^{\circ} \mathrm{C}$

$V_{s a}($ Debit Udara Supply) $\quad=425,14 \mathrm{~L} / \mathrm{s}$

Rumus yang digunakan dalam menghitung kapasitas pemanasan adalah persamaan berikut.

$$
Q_{\text {reheat }}=1,23 \times\left(T_{s a}-T_{l a}\right) \times V_{s a}
$$

Dimana :

$Q_{\text {reheat }}($ Kapasitas Pemanasan $)=3.660,45 \mathrm{Watt}$ $\Delta T$ (Perbedaan temperatur) $\quad=7^{\circ} \mathrm{C}$ $V_{s a}$ (Debit udara supply) $\quad=425,14 \mathrm{~L} / \mathrm{s}$

\section{Perhitungan Pressure Loss Supply dan Return Air Duct}

Dari hasil perhitungan kalor total, maka didapat unit dari suatu produsen AC internasional, dengan debit sebesar 949,6 L/s. Debit ini yang akan digunakan untuk perhitungan pressure loss air duct. Tentukan jumlah diffuser yang akan menjadi outlet udara dari setiap unit. Untuk nilai debit udara balik $\left(V_{\text {return }}\right)$ maka dari nilai debit udara supply dikurangi dengan debit udara fresh air. Debit udara fresh air merupakan $15 \%$ dari debit udara supply.

Tabel 5. Nilai Debit Supply dan Jumlah Diffuser

\begin{tabular}{|c|c|c|c|}
\hline $\begin{array}{c}\boldsymbol{V}_{\text {supply }} \\
\text { (Lps) }\end{array}$ & $\begin{array}{c}\text { Jumlah } \\
\text { Diffuser }\end{array}$ & $\begin{array}{c}\boldsymbol{V}_{\text {supply }} \text { per } \\
\text { Diffuser } \\
\text { (Lps) }\end{array}$ & $\begin{array}{c}\text { Ukuran } \\
\text { Diffuser }\end{array}$ \\
\hline 949,6 & 8 & 118,7 & $\begin{array}{c}\text { Ceiling } \\
\text { HEPA } \\
\text { Filter }\end{array}$ \\
\hline
\end{tabular}

Tabel 6. Nilai Debit Return dan Jumlah Grille

\begin{tabular}{|c|c|c|c|}
\hline $\begin{array}{c}\boldsymbol{V}_{\text {return }} \\
\text { (Lps) }\end{array}$ & $\begin{array}{c}\text { Jumlah } \\
\text { Grille }\end{array}$ & $\begin{array}{c}\boldsymbol{V}_{\text {return }} \text { per } \\
\text { Grille (Lps) }\end{array}$ & $\begin{array}{c}\text { Ukuran } \\
\text { Grille }\end{array}$ \\
\hline 807,16 & 2 & 403,58 & $\begin{array}{c}600 \mathrm{~mm} \times \\
350 \mathrm{~mm}\end{array}$ \\
\hline
\end{tabular}

Setelah menentukan jumlah diffuser dan debit setiap diffuser dan grille, selanjutnya membuat skema aliran udara pada ruangan, dan memilih saluran ke outlet terjauh untuk menghitung pressure loss. 


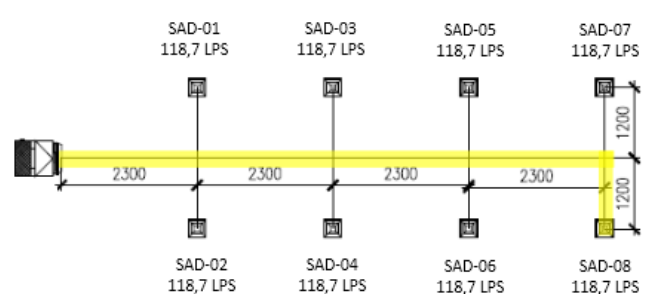

Gambar 8. Skema Saluran Terjauh Supply Air

Tabel 7. Ukuran Supply Air Duct

\begin{tabular}{|c|c|c|c|c|c|}
\hline Duct & $\begin{array}{c}\text { Debit } \\
(\mathbf{L} / \mathbf{s})\end{array}$ & $\mathbf{P a / m}$ & \multicolumn{2}{|c|}{$\mathbf{H} \mathbf{( m m )}$} & $\begin{array}{c}\mathbf{v} \\
\mathbf{X} \mathbf{~ W} \mathbf{( m )}\end{array}$ \\
\hline $\begin{array}{c}\text { Unit - } \\
\text { Cabang 1 }\end{array}$ & 949,6 & 0,8 & 450 & 400 & 5,68 \\
\hline $\begin{array}{c}\text { Cabang 1 - } \\
\text { Cabang 2 }\end{array}$ & 712,2 & 0,8 & 450 & 350 & 5,3 \\
\hline $\begin{array}{c}\text { Cabang 2 - } \\
\text { Cabang 3 }\end{array}$ & 474,8 & 0.8 & 350 & 300 & 4,8 \\
\hline $\begin{array}{c}\text { Cabang 3 - } \\
\text { Elbow }\end{array}$ & 118,7 & 0,8 & 200 & 200 & 3,4 \\
\hline $\begin{array}{c}\text { Elbow - } \\
\text { SAD-8 }\end{array}$ & 118,7 & 0,8 & 200 & 200 & 3,4 \\
\hline
\end{tabular}

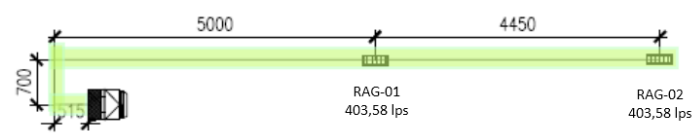

Gambar 9. Skema Saluran Terjauh Return Air

Tabel 8. Ukuran Return Air Duct

\begin{tabular}{|c|c|c|c|c|c|}
\hline Duct & $\begin{array}{c}\text { Debit } \\
(\mathbf{L} / \mathbf{s})\end{array}$ & $\mathrm{Pa} / \mathrm{m}$ & $\begin{array}{c}\mathrm{H} \\
\mathrm{XW}\end{array}$ & m) & $\begin{array}{c}\mathbf{v} \\
(\mathbf{m} / \mathbf{s})\end{array}$ \\
\hline $\begin{array}{c}\text { RAG-02 to } \\
\text { RAG-01 }\end{array}$ & 403,58 & 0,80 & 300 & 300 & 4,80 \\
\hline $\begin{array}{l}\text { RAG-01 to } \\
\text { Elbow } 1\end{array}$ & 807,16 & 0,80 & 450 & 400 & 5,70 \\
\hline $\begin{array}{c}\text { Elbow } 1 \text { to } \\
\text { Elbow } 2\end{array}$ & 807,16 & 0,80 & 450 & 400 & 5,70 \\
\hline $\begin{array}{c}\text { Elbow } 2 \text { to } \\
\text { IU-2 }\end{array}$ & 807,16 & 0,80 & 450 & 400 & 5,70 \\
\hline
\end{tabular}

Dengan memasukkan parameter debit dan friction loss per meter $(\mathrm{Pa} / \mathrm{m})$ pada duct sizer, maka didapat kecepatan dan ukuran duct.

\section{- Pressure Loss pada Saluran Lurus}

Menghitung pressure loss pada saluran lurus, digunakan persamaan (5) dan (4). Sehingga hasil perhitungannya tertuang pada tabel 9 dan 10 .

\section{- Pressure Loss pada Sambungan}

Sedangkan untuk menghitung pressure loss sambungan digunakan rumus (6). Sehingga hasil perhitungannya tertuang pada tabel 11 dan 12 .
Tabel 9. Pressure Loss Saluran Lurus Udara Supply

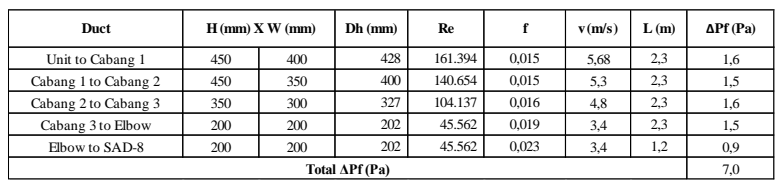

Tabel 10. Pressure Loss Saluran Lurus Udara Return

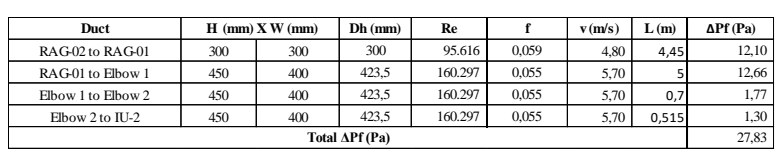

Tabel 11. Pressure Loss pada Sambungan Udara Supply

\begin{tabular}{|c|c|c|c|r|}
\hline Duct & $\mathbf{v}(\mathbf{m} / \mathbf{s})$ & $\mathbf{V p}(\mathbf{P a})$ & $\mathbf{C}$ & $\mathbf{T P}(\mathbf{P a})$ \\
\hline Elbow 1 & 4,2 & 10,62 & 0,20 & 2,12 \\
\hline \multicolumn{5}{|c|}{ Total TP $(\mathbf{P a})$} \\
\hline
\end{tabular}

Tabel 12. Pressure Loss pada Sambungan Udara Return

\begin{tabular}{|c|r|r|r|r|}
\hline Duct & $\mathbf{v}(\mathbf{m} / \mathbf{s})$ & $\mathbf{V p}(\mathbf{P a})$ & \multicolumn{1}{|c|}{$\mathbf{C}$} & $\mathbf{T P}(\mathbf{P a})$ \\
\hline Elbow 1 & 5,70 & 19,56 & 0,20 & 3,91 \\
\hline Elbow 2 & 5,70 & 19,56 & 0,20 & 3,91 \\
\hline \multicolumn{5}{|c|}{ Total TP (Pa) } \\
\hline
\end{tabular}

Nilai C untuk elbow dapat dilihat pada tabel berikut.

Tabel 13. Nilai C untuk Elbow

CR3-1 Elbow, Smooth Radius, Without Vanes

\begin{tabular}{|c|c|c|c|c|c|c|c|c|c|c|c|}
\hline \multirow[b]{3}{*}{$r / W$} & \multicolumn{11}{|c|}{$C_{p}$ Values } \\
\hline & \multicolumn{11}{|c|}{$\mathrm{H} / \mathrm{W}$} \\
\hline & 0.25 & 0.50 & 0.75 & 1.0 & 1.50 & 2.0 & 3.0 & 4.0 & 5.0 & 6.0 & 8.0 \\
\hline 0.50 & 1.53 & 1.38 & 1.29 & 1.18 & 1.06 & 1.00 & 1.00 & 1.06 & 1.12 & 1.16 & 1.18 \\
\hline 0.75 & 0.57 & 0.52 & 0.48 & 0.44 & 0.40 & 0.39 & 0.39 & 0.40 & 0.42 & 0.43 & 0.44 \\
\hline 1.00 & 0.27 & 0.25 & 0.23 & 0.21 & 0.19 & 0.18 & 0.18 & 0.19 & 0.20 & 0.21 & 0.21 \\
\hline 1.50 & 0.22 & 0.20 & 0.19 & 0.17 & 0.15 & 0.14 & 0.14 & 0.15 & 0.16 & 0.17 & 0.17 \\
\hline \multirow[t]{2}{*}{2.00} & 0.20 & 0.18 & 0.16 & 0.15 & 0.14 & 0.13 & 0.13 & 0.14 & 0.14 & 0.15 & 0.15 \\
\hline & \multicolumn{11}{|c|}{ Angle Factor $K$} \\
\hline$\theta$ & $\mathbf{0}$ & 20 & 30 & 45 & 60 & 75 & 90 & 110 & 130 & 150 & 180 \\
\hline$K$ & 0.00 & 0.31 & 0.45 & 0.60 & 0.78 & 0.90 & 1.00 & 1.13 & 1.20 & 1.28 & 1.40 \\
\hline
\end{tabular}

\section{- Pressure Loss Air Duct Total}

Setelah pressure loss pada saluran udara supply dan return dihitung, maka selanjutnya menghitung pressure loss air duct total dengan menjumlahkan pressure loss pada saluran lurus dan sambungan.

Tabel 14. Nilai Pressure Loss Air Duct Total

\begin{tabular}{|c|c|c|}
\hline$\Delta \mathbf{P}_{f}(\mathbf{P a})$ & TP $(\mathbf{P a})$ & $\begin{array}{c}\text { Total Pressure } \\
\text { Loss } \mathbf{( P a})\end{array}$ \\
\hline 34,9 & 9,95 & 44,85 \\
\hline
\end{tabular}




\section{Menentukan Kebutuhan Filter}

Setelah memilih unit dan menghitung pressure loss pada air duct, maka dapat diketahui kebutuhan filter sesuai dengan fungsi ruangan.

Untuk ruang NICU, termasuk pada klasifikasi inpatient care dan AII rooms. Sehingga minimal diperlukan filter dengan nilai MERV 7 dan MERV 14. Prefilter diperlukan untuk mengurangi maintenance pada filter dengan nilai MERV lebih dari 7. Nilai efisiensi filter setiap kategori MERV dapat dilihat pada tabel 2 , sesuai dengan ukuran partikel yang disaring. Tabel berikut merupakan tabulasi kebutuhan filter untuk Indoor Unit.

Tabel 15. Tabulasi Kebutuhan Filter

\begin{tabular}{|c|c|c|}
\hline Filter 1 & Filter 2 & Filter 3 \\
\hline MERV-7 & MERV-11 & MERV-15 \\
(Built in unit) & (Built in unit) & (In ceiling) \\
\hline
\end{tabular}

\section{PENUTUP}

\section{Kesimpulan}

1. Salah satu upaya untuk mengurangi Hospitalacquired Infections (HAIs) pada ruang NICU dan sekitarnya, adalah dengan merancang sistem tata udara khusus dengan parameter yang dikondisikan adalah mengatur Air Change Rate, mengatur tingkat kebersihan, mengatur kelembaban dan tekanan udara ruangan sesuai dengan ASHRAE HVAC Design Manual for Hospital and Clinics.

2. Kapasitas pendinginan dari hasil perhitungan adalah sebesar 8,805 kW. Sedangkan kapasitas pemanasan untuk electric heater adalah sebesar 3,660 kW.

3. Pada saluran distribusi udara yang dirancang, didapat total pressure loss adalah sebesar 44,85 Pa.

4. Terdapat Pre-Filter, Medium Filter yang builtin unit dan HEPA Filter yang akan diletakkan di ceiling ruangan.

\section{Saran}

Perhitungan debit infiltrasi dapat menggunakan perhitungan melalui celah-celah pintu dan jendela untuk memperoleh hasil perhitungan kapasitas yang lebih optimal.

\section{DAFTAR PUSTAKA}

Abduladheem, A. et al. (2013) 'Ventilation Air Distribution in Hospital Operating', International Journal of Science and Research, 2(11), pp. 81-85. Available at: www.ijsr.net.
Azimi, P. and Stephens, B. (2013) 'HVAC Filtration for Controlling Infectious Airborne Disease Transmission in Indoor Environments: Predicting Risk Reductions and Operational Costs', Building and Environment. doi: 10.1016/j.buildenv.2013.08.025.

Hemavathy, V., Bhaskaran, G. and Sudha, Y. (2016) 'A Descriptive Study to Assess the Knowledge on Infection Control among Staff Nurses in I.C.U in Selected Hospitals in Chennai', International Journal of Science and Research (IJSR), 5(1), pp. 1341-1343. doi: 10.21275/v5i1.nov152925.

Irfan, Syed Faheem; Syed, Mujeeb Ali; Syed Suleman; Syed, Obaid Ur Rahman; Syed, W. U. (2017) 'Design for Thermal Comfort during Summer \& Psychometry Tool for Human Comfort', International Journal of Science and Research (IJSR), 6(2), pp. 276283. Available at: https://www.ijsr.net/archive/v6i2/ART20176 09.pdf.

Koenigshofer, D. (2013) HVAC Design Manual for Hospitals and Clinics. 2nd edn. ASHRAE.

Licina, D. et al. (2016) 'Concentrations and Sources of Airborne Particles in A Neonatal Intensive Care Unit', PLOS ONE, 11(5), pp. 1-17. doi: 10.1371/journal.pone.0154991.

Rudoy, W. (1980) Cooling and Heating Load Calculation Manual. ASHRAE.

Soleha TU, Rukmono P, H. G. (2015) 'Kualitas Mikrobiologi Udara di Ruang Neonatal Intensive Care Unit ( NICU ) Air Microbiological Quality from Neonatal Intensive Care Unit ( NICU ) General', Majority, 4, pp. 143-148.

Sundari, T. et al. (2017) 'Peran Sistem Tata Udara dalam Pencegahan dan Pengendalian Infeksi Di Ruang Isolasi Airborne RSPI Prof . Dr . Sulianti Saroso', The Indonesian Journal of Infectious Diseases, 4(1).

Wang, S. K. (2000) Handbook of Air Conditioning and Refrigeration, Choice Reviews Online. McGraw-Hill. doi: 10.5860/choice.32-0959. 